\title{
Women's empowerment model in home-based industries in East Java Province, Indonesia
}

\author{
Model pemberdayaan perempuan pada industri rumah tangga di \\ Provinsi Jawa Timur, Indonesia
}

\author{
Emy Susanti \& Siti Mas'udah \\ Department of Sociology, Faculty of Social and Political Sciences, \\ Universitas Airlangga, Surabaya, Indonesia \\ Jalan Dharmawangsa Dalam, Surabaya 60286 \\ E-mail: siti.masudah@fisip.unair.ac.id
}

\begin{abstract}
This study aimed to classify the role of women, gender and characteristics of home-based industries that were managed by women in two cities of East Java Province. This study also tried to identify strengths, weaknesses and challenges faced by these women, especially impoverished women. The research employed qualitative method supported by quantitative data. The data collected through structured interviews guided by questionnaires and indepth interviews. Three main results were attained. First, it was related to the characteristics of women workers, the role of multi-burdened women, the flexible working hours, formal education but unrelated to work, and low income but still importantly needed to support economic condition. Second, three networks were found: network between manager/owner and workers that was informal and family-oriented, network between managers and local government for marketing and training, and network with the private sector for access to capital and business development. Third, the model of empowering small home-based industries should consider the specific needs of women. In other words, there is a requisite for practical and strategic gender needs that has to be comprehended and become the basis for the planning and development to conduct activities and programs for women.
\end{abstract}

Keywords: women, poverty, gender and development, small-scale industries, women's empowerment

\begin{abstract}
Abstrak
Studi ini dimaksudkan untuk memetakan peran perempuan, relasi gender dan karakteristik industri kecil rumahan ('home based industry') yang dikelola dan mempekerjakan perempuan di Provinsi Jawa Timur. Studi ini juga dimaksudkan untuk mengidentifikasi kekuatan, kelemahan serta tantangan yang dihadapi perempuan, khususnya perempuan miskin dalam industri kecil rumahan ('home based industry') di Provinsi Jawa Timur. Penelitian ini menggunakan metode kualitatif didukung dengan data kuantitatif. Data primer dikumpulkan dengan metode wawancara terstruktur menggunakan kuesioner dan wawancara mendalam menggunakan pedoman wawancara. Tiga hal penting hasil penelitian ini meliputi; 1) Perempuan pekerja industri rumahan menunjukkan peran yang multi 'burden', jam kerja fleksibel, pendidikan formal cukup tinggi tetapi tidak ada pendidikan khusus terkait pekerjaan, kontribusi ekonomi dalam keluarga penting walaupun pendapatan relatif rendah; 2) berkaitan dengan jaringan kerja yang terbentuk dalam Industri Kecil Rumahan ada tiga jenis; a) jaringan kerja antara pengelola atau pemilik industri kecil rumahan dengan pekerjanya bersifat kekeluargaan dan informal, b) jaringan kerja yang terjalin antara pengelola dengan Pemerintah Daerah yaitu dalam hal pemasaran dan pelatihan, c) jaringan kerja dengan swasta terjalin dalam hal akses permodalan dan pengembangan usaha; belum ada jaringan kerja yang terbentuk antar perempuan pengelola maupun dengan pekerja dalam industri rumahan; 3) berkaitan dengan model pemberdayaan perempuan, belum ada model khusus pengembangan industri kecil rumahan yang dikelola dan mempekerjakan perempuan. Perumusan model pemberdayaan perempuan miskin dan strategi pengarusutamaan gender yang lebih menjamin secara optimal diperlukan untuk pengembangan industri kecil rumahan ('home based industry') yang dikelola dan mempekerjakan perempuan miskin di Provinsi Jawa Timur.
\end{abstract}

Kata kunci: perempuan, kemiskinan, gender dan pembangunan, industri kecil, pemberdayaan perempuan 


\section{Introduction}

Development of microscale industries based on the household is supported by married women workers, especially impoverished women. Family demands for impoverished women have encouraged them to work on the household industry. Home-based industries have greatly developed in many regions in Indonesia, including some regions in East Java Province. From the productivity point of view, during economic crisis, small-scale industries are still productive and even able to contribute to the state's income through exports. Meanwhile, from the workforce, small industry sectors are able to absorb labor from different circles, especially less educated and impoverished women who acquire no skill and have responsibility for the household. With respect of this fact, home-based industries have helped to develop East Java Province, mainly for Surabaya and Pamekasan.

The labor involvement of impoverished women in home-based industries, as well as other informal sectors, is relatively high. This fact is due to limited job opportunities in the formal sector for women, especially those lacking of education. In addition, limited access to education and training, as well as household responsibilities render these women difficult to find work and follow very tight hours in the formal sector. Women who work in a small industry sector are generally impoverished married women. As the sector does not require formal education and they have more flexible working hours, this enables them to work at home or around their neighborhood and combine their responsibility at work with their housework.

Some previous researchers have argued that such an environment affects these women's ability to fulfill their family needs. Besides, impoverished women hold responsibility and contribute towards the survival of their impoverished households (Surbakti 1991, Susanti 2009). Other Studies about women and impoverished households also show the importance of women's role as the main wage earner in their household (Ihromi 1990). Moreover, the result of the study conducted in East Java showed that impoverished women did various works, with a majority of those working in the informal sectors for more than 8 hours per day, and earning relatively small wages (Susanti 2010).

Despite providing income for these women, these informal sectors also encounter many problems, including capitals and access of marketing products. In addition, the regional government has not reached these industries in general, accordingly, there is no policy or program regarding the need of woman labors involved in these sectors. On the other hand, micro-economic development-based society has been proven to succeed as the major economic development in Indonesia. Therefore, micro-economic development, such as home-based industries, has played a significant role in supporting the success of economic development in Indonesia. The success of small home-based industries can be optimized when women with all their potential strength and networks are positioned as 'subjects' of development. All of these require sufficiently accurate data and a holistic approach as the basis in the formulation of development policy so that women can become a strategic part in Indonesian economic development.

Recently, the Indonesian government has launched Gender Mainstreaming Strategy (GMS) in the entire development process (Presidential Instruction Number 9 Year 2000 regarding gender mainstreaming in national development). The Gender Mainstreaming Strategy (GMS) is also actively applied in other countries such as Saudi Arabia (Shash \& Forden, 2016), Bolivia (Hippert, 2011), Ntcheu \& Dedza in Malawi (Mudege et al., 2015), and Brazil (Waltz, 2016; Mello \& Schmink, 2016). This policy in reality brings consequences that all local governments should conform to the women's empowering program in all sectors. Especially in micro-economic development, gender mainstreaming policy is very relevant because many impoverished women are involved in small industries, especially small home-based industries. Accordingly, efforts to develop small home industries cannot ignore gender mainstreaming policy, and a model to empower impoverished women is required to assure optimum development. The development of small home-based industries will improve the welfare of impoverished women involved in the industries, as well as their family. Hence, aside from sustaining 
a successful economic development, developing small home-based industries involves impoverished women to participate in the reduction of poverty.

Development approach for the past few decades has been more oriented to economic development. At the current rate of progress, development approach begins to shift its focus on 'human resource' development and social welfare. Development approach based on gender development has evolved over time and been implemented in many countries in the world.

The development of gender perspective approach was initiated by welfare approah in 1970s, followed by efficiency approach in 1980s, and then empowerment approach. Although those approaches have drawn on gender-perspective, they put an emphasis on a different focus of development, such as the role of women and gender relations. As a result, the strategy and development program created based on the different approaches also vary.

Welfare Approach of Gender Perspective view women as passive recipients and not as subject of development. In this approach, the role of women in society deemed to be the most important and effective is childrearing role. The approach focuses more on women's role in reproductive health, and considers men to have productive role. Implementation of this approach is set as 'top down' processoriented to the women's reproduction to improve family welfare. This approach stresses more on the needs of practical gender issues related to reproductive role of women. This approach regards women as part of development problem that need to be addressed rather than as resources. Consequently, this approach often results in turning women to be highly dependent and does not facilitate them to be more self-sufficient since it fails to consider the potency and the role of women to boost the success of the development programs (Moser 1996:197-198).

Next approach is Efficiency of Gender Perspective that focuses on the efficiency of women's role, with an assumption that bringing women into production will automatically serve as a means of achieving gender equality. According to this efficiency approach, development will only be successful and efficient if women are involved in the development process (Moser 1996:205-206). However, the assumption that the women's participation in the economy may increase gender equality has been widely criticized as there are some factors that hamper women's participation, such as having low levels of education and lacking of knowledge in technology. Even though the role of women is very important for the success of economic development, their role in development does not automatically increase the status of women to achieve gender equality.

The latest approach in gender perspective was Women's Empowerment. This approach was developed as a result of dissatisfaction with initial approaches. This approach is different from two previous approaches in terms of the reasons, dynamics and structure of oppression to women, which is also questioned. This approach is based on the assumption related to power relations and development and attempts to identify power in order to improve its independence and internal power of women. This approach does not emphasize the "status" of women to men; instead, it is intended to empower women through redistribution of power in the society.

Furthermore, government at all levels hold a responsibility to implement the development of gender perspective approach. The development approach to the construction of gender perspective is promoted to encourage government to take action and special efforts to improve the status of women. Accordingly, Moser (1991) introduces the concept of the specific needs of women formulated into the concept of Gender Needs that includes practical gender needs and strategic gender needs. Practical gender needs are defined as the specific needs of women in short term period to meet daily needs, while the Strategic Gender Needs describes the specific needs of women in long term period to improve their status in the society. Therefore, these specific conditions and needs of women should be taken into consideration in the development policy and program for women. Although the primary orientation of women's empowerment in development programs is strategic gender needs aiming at 
achieving gender equality in the long run, it does not necessarily mean to overlook practical gender needs. It is due to the fact that practical gender needs serve as the basis and means of realization of strategic gender needs.

Gender Approach and Development (GAD) is also known as the empowerment approach. This approach notices the importance of all aspects of women's lives and all the work done, as well as the roles of women in both production and reproduction, and also their private and public roles. The focus of this approach is not only to increase women's income in order to be independent but also to build equal gender relations, namely the creation of a social construction that governed the rights, obligations, roles and responsibilities relatively to men and women. GAD analyzes social problems in a holistic manner, and views people's lives in a variety of dimensions (i.e. political, social, economic, and cultural dimensions) organized based on gender relations.

GAD regards increasing women's roles as a means of creating more harmonious and balanced gender relations. Furthermore, policy intervention is not solely aimed at women's practical interest in the strategic interests of women. Currently, GAD approach has been widely applied in developing countries, including Indonesia, because this approach is considered addressing the most basic needs of women that accommodate all of their aspects.

Development in favor of the people requires the availability of policy support from policy makers (government) in accordance with the vision of change. The government should also support efforts to avoid creation of discriminatory policies, particularly against women. As members of the public, women are also entitled to be involved in the decision-making process in development. The neglect of women in the development process adversely affect women. The negative impacts of development on women are due to problems in the planning stages of development as follows: (1) Paying no attention to women's productive role that has traditionally been held by women; (2) Strengthening the values of a society where women are restricted in domestic routines, such as household tasks and raising children (caring roles); (3) Strengthening the social and cultural values regarding the most suitable jobs for women in developing societies (gender division of labor).

To promote participation and involvement of women as subjects in development, it is required to develop an analysis that understand exactly the different forms and participation between men and women. Accordingly, Technical Analysis of Gender is applied due to its ability to provide a more perfect view on difference and interdependence between men and women in the overall development process. In addition, analysis of gender is very important for us to identify the different levels and kinds of benefits resulting from development for men and women.

Through Presidential Instruction No. 9 year 2000, the Indonesian Government has determined to implement gender mainstreaming in the development process in all areas/sectors. Gender-perspective as mainstream requires to be continuously pursued by all parties, especially those directly concerned with the development planning process.

In implementing gender approach in the development process, there are a few points to note: (1) The need to examine the development sector has been carried out as evaluation for the upcoming project. It is necessary to analyze whether the development has optimally benefited both men and women, and how much equality has been achieved between men and women in the development both as the perpetrators and beneficiaries; (2) It is the need for a mean to assist these sectors in examining the success of development sectors; (3) It is the need of support from government agencies and other related sectors to prepare necessary data and information for reviewing the successful industrial development efforts .Consequently, it is necessary to agree upon the basic concept of gender analysis for the development planning. It is important to influence commitment and capability to implement gender perspective in developing programs in the regions. 
The research questions of this study are: (1) How are the characteristics, the women potency and gender relations in small home-based industries in East Java Province, in which women become managers and workers? (2) How are holistic networks developed by women as managers and as workers in small home-based industries in East Java Province? (3) Which women's empowerment model can assure optimum development of small home-based industries managed and staffed by women in East Java Province?

\section{Research Method}

Social setting of this study was a small home-based industries managed and staffed by women. This study included two regions, namely Pamekasan for small traditional batik and processed food industries, and Surabaya for small crafts and processed food industries. Particularly, this research was conducted on seven small home-based industries in Surabaya and five small home-based industries in Pamekasan.

The research employed qualitative method supported by quantitative data. Primary data were obtained through questionnaires by conducting interviews to 120 women working in the home-based industries (70 women in Surabaya and 50 in Pamekasan). In addition, in-depth interviews using interview guideline were conducted to 12 women managing home industries, 5 local government officers, and administrators of the Association of Indonesian Woman Entrepreneurs and Dekranasda. Researchers were equipped with voice recorder and video recorder in conducting the in-depth interview.

Secondary data were obtained from local governments (Pamekasan and Surabaya) and from East Java Provincial Government, especially from the Office of Industry and Commerce, the Regional Development Planning Board of East Java and the Office of Small-Scale Industry and Cooperatives. Data analysis applied quantitative techniques for data collected from questionnaires and data analysis for qualitative data, such as in-depth interview, used transcript, data categorization, empirical summary, and theoretical analysis.

\section{Result and Discussion}

\section{Characteristics, women potency and gender relations in small home-based industries in} Surabaya and Pamekasan

Characteristics, women potency, and gender relations in small home-based industries analyzed in the discussion were related to the characteristics of women workers based on age, education, reason for choosing to work in a small industry, wage, difficulties at work, problem of childrearing, domestic labor arrangement, influence of mothers around working environment, health care facilities, and knowledge regarding labor legislations.

The majority of women workers in small home-based industries was from 25 to 40 years old (75.7 percent). Workers aged above 40 years old were relatively fewer than those from other age groups, and it was also rare to find young women workers aged from 1-25 years in home-based industries. This showed that women workers in home industries were mainly housewives working in between their domestic activities in order to help their husbands earn a living.

In terms of formal education, women workers in small home-based industries actually had adequate formal education. As much as 87.1 percent of the workers graduated from senior high schools, thus this showed that despite having senior high school diploma that might enable them to work in formal sector, these women chose to work in small home-based industries located close to home and that also offered more flexible working hours. 
Women workers in these home-based industries suggested a number of reasons for working in the industries, which included occupying spare time, earning extra income for the family (the husbands were currently unemployment), earning a living (their husband were sick or died), or any other reasons. As much as $82.9 \%$ of the workers claimed that gaining additional income for their family as their main reason, while only $14.3 \%$ stated that their reason was to occupy their spare time. Accordingly, the data showed that most of these women worked in small home-based industries because they wanted to help to earn extra income to fulfill their family needs.

Women workers in home-based industries in general have been working at the same place for quite a long time and would not move to work in another place. Most workers have been working for 1-5 years, and some even for more than 6 years.

The data also showed that 58.6 percent of these women earned less than Rp.500.000, while the remaining 41.4 percent gained between Rp.500.000-1.000.000. Their earnings were still below the regional minimum wage because their work was still in domestic environment that had flexible hours and rules unlike those of medium and large industries, as revealed by the manager of Pamurbaya cracker industry in Gunung Anyar.

\section{Constraints in working and domestic tasks}

Results of this study indicated that the biggest obstacle faced by these women in home-based industries concerned with managing the time between working and doing domestic chores. As much as $871 \%$ stated that domestic chores were the "problem". Mothers from low-income families had to play 'double' roles because of their family needs.

Concerning the problem of childrearing, especially during working hours, this research revealed that most women stated that the children were 'left at home alone' when their mothers were at work (75.7 $\%)$ and only a few of them who entrusted their children to relatives or neighbors (18.6\%). By leaving their children home alone, there would be less supervision for their development and activities. However, they realized that this is the risk that they had to take in order to meet their economic needs.

This study also revealed that not only that they had to work, as wives they were still held responsible for household chores. The majority of the women who worked at home industries stated that they must do household chores on their own (98.6\%). This implied that their husbands did not take a share in domestic works. This fact showed that an understanding of gender relations in the household was clearly unbalanced. The wife still had to be responsible for household chores despite having to work in the public sector. Hence, working women were still required to work in the kitchen, and take care of her husband and children, yet remain professional in the workplace.

In addition to family factors, environmental influence was also very significant for women to do other works outside the household chores. If the home environment 'supported' women to work, then it indirectly encouraged others to join, especially when they came from low-income families, then there was no other alternative for the wives to work together to support their families.

\section{Facilities and employment}

This study showed that more than half of the women working in small industries (57.1 percent) obtained health benefits from work in a form of free medical services or extra money for health treatment. This was revealed by the manager of Pamurbaya crackers industry, Gunung Anyar.

A different matter was also revealed by the manager of marine processing product in Sukolilo, Kenjeran. Women are given specific rights due to their reproductive functions, such as menstruation, pregnancy, childbirth and breastfeeding. Therefore, they need special protection to maintain their 
reproductive function and productivity at the workplace. The rights of women workers are protected by law that include to have menstrual and maternity leave, breastfeed, limit their working hours, gain health benefits, and have security. Nevertheless, the findings of this study revealed that nearly all these women workers were not aware of labor legislation including the rights of working women.

\section{Women's networks with their community in home industries}

This study focused on 12 home industries managed and staffed by women, in which seven of them were in Surabaya, while the other five were in Pamekasan. In this research, the characteristics of marketing in these home industries were mostly spontaneous, family-oriented, traditional, sporadic and not well-planned. However, not all of this spontaneous and traditional marketing was not effective as revealed by the manager of Pamurbaya crackers in Gunung Anyar, Surabaya, which marketed their products on their own and with the help from any personal relations they had.

Being close to existing customers was one of the advantages in marketing for small business owners, such as Mrs. Lianah. Nonetheless, the disadvantage was that she had less new customers. In developing small business, she needed to look for new customers, as well as to retain existing customers. Retaining existing customers could be done by offering free products to as rewards so that they remained loyal and continued to buy the products.

If home industries moved to creative sectors, such as handicraft, they could gain product positioning since creative sectors were favored by foreign markets. Besides, developing exports such as handicraft was assigned a special place in the government programs. This concerned with creating unique products that offered more advantages as stated by Sri Sulatiningsih (Manager of Handicraft in Kedungsari, Surabaya). Moreover, the government always promoted handicraft products for not only local, but also national as well as international exhibitions.

Nevertheless, handicraft products also had face challenges in marketing as there were countless number of competitors everywhere. If the products or services render did not offer any excellence, they would be difficult to compete. High quality products were not enough, and the products had to be able to meet customers' needs. Along with the advancement of technology, the industries were also required to adapt and innovate in creating their products in order to compete since the customers have also constantly changed from time to time.

Dependence towards exhibitions held by the government sometimes became an obstacle for the marketing of home industries because of government and exhibition organizers who were not serious in handling the programs. Frequently, local government was not serious to exhibit local products to empower the home-based industries. The Government only pursued targets without making clear output plans. Outputs, including target sales, the total number of visitors, and cooperation with modern markets such as malls and supermarkets after the exhibition, were less thought of by the local authorities in organizing exhibitions.

If owners released the products of small home industries to modern market without the protection of the government, they faced bigger risks due to complicated rules set by the modern market that included quality of the products or late payment. Small home-based industries with limited capital would not be able to survive if the production continued while the products were not well sold or even returned.

For home industries producing food and beverages, it is even more difficult if the potential market at local level was not supportive towards quality competition. Not all malls could accept the products because of undurability, except when there were any cooperation programs or invitation to join such programs. It is very difficult to develop good marketing as revealed by the manager of herbal drinks in Jemursari and the manager of bakery business in Bubutan, Surabaya. Marketing for food and 
beverage products had to be strengthened in the local markets through publications in location visited by lots of potential buyers or by distributing them to food stalls or street vendors provided by the government. By adding products value, displaying product samples with information concerning the price, materials and other necessary details, it could help the customers to remember the products and promote them through word of mouth.

In terms of training, almost all of the owners or managers of small home industries had received training from government agencies. They were trained more on how to improve the quality of the product, how to pack, and how to access capitals and marketing as stated by the manager of Pamurbaya crackers, Gunung Anyar and the manager of handicraft products, Kedungsari. Similar statement was also suggested by the manager of Marine Processing Product, Sukolilo, Kenjeran and the manager of herbal drinks, Jemursari.

Capital access for small business in Surabaya was administered by the Office of Cooperatives and Small-Medium Enterprises, while facilities for production tools and business legalities were managed by the Office of Industry and Commerce. However, according to the owners or managers, assistance provided by government agencies are less effective as stated by the manager of Pamurbaya crackers, Gunung Anyar and managers of mangrove processing product, Wisma Kedungasem. Meanwhile, the owners of other industries suggested a different idea concerning capital loan from cooperatives as stated by the manager of marine processing product, Sukolilo Kenjeran. For handicraft business, the manager from Kedungsari also claimed to have obtained some assistance from the government (the Office of Industry and Commerce) once.

\section{Women networks with investors and marketing for small-scale industries in Pamekasan regency}

The development of small industry in Pamekasan Regency has led to batik industry as the best product. Aside from the fact that producing batik was a tradition, this product has also been given a special attention from the government and become a featured product promoted by Pamekasan Government. The society preferred to produce batik to other industries, such as marine commodities that were their traditional products used only as daily consumptions.

Batik Arifil was established in the beginning of the 1980s. This small home-based industry was owned by Hj. Nurul Afrida who continued her parents' business in the field of batik and diamond. Her parents wanted their business to be continued and developed due to its highly historical value. Initially, batik business inherited from her parents had no name because batik was a Madurese tradition. Almost every batik was not registered and had no brand simply in order to penetrate the market and also easily follow trends in batik at that time.

The marketing of batik Arifil was initially done door-to-door, or promoted directly to its customers. However, it is different from now. According to $\mathrm{Hj}$. Nurul Afrida, she continued this business from her mother, therefore she has already learned how to develop and penetrate the market outside Madura. She wanted to expand her market because she just thought of how her employees could have some extra money for their family as they consulted to her about needing jobs.

At that time, most of her employees were her students who came to see her in Islamic boarding school every night. Upon finishing study in her Islamic boarding school, every student had been trained how to create batik in order to become an entrepreneur. Nevertheless, since becoming an entrepreneur required capital and persistence, many of them were not able to compete. As a result, they preferred to continue working for $\mathrm{Hj}$. Nurul Afrida.

Hj. Nurul Afrida's batik workshops were not in her house, but in the her students' instead. One of the reasons for not having the workshop at her house because her house did not have enough space to 
accommodate the working activities, moreover, it was also used for the study of religion. In addition, $\mathrm{Hj}$. Nurul Afrida stated, "It is uncomfortable for me if (as a religion teacher) I conduct business in my house. It is not ethical. Moreover, it will also be inconvenient for those who study at my house".

In doing her business, $\mathrm{Hj}$. Nurul Afrida never forced herself to make batik at all times. Every day, about 3-5 workers maintained the cleanliness of batik cloth or made batik. Unless she had many orders, she would not call some more workers to make batik intensively. Furthermore, Hj. Nurul Afrida did not always ask them to work with her. She gave freedom to her workers to develop their skills in batik making. If her employees wanted to develop their own business independently, she did not object. The most important thing for her was to be involved in batik making industry seriously and meticulously so as not to ruin the image and market of Madurese batik. Currently, many of her employees have already opened their own batik business. Some of them even have been able to penetrate the market outside Madura. One of them was $\mathrm{Hj}$. Hosniyah.

Arifil batik business owned by $\mathrm{Hj}$. Nurul Afrida received a personal loan from Bank Rakyat Indonesia (BRI) around 5 years ago amounting to 20 million rupiah using proof of motor vehicle ownership (BPKB) as guarantee. For her, the loan was insufficient because the segment for her batik was the upper middle high class that required her to have quite a large amount of capital to purchase good quality raw materials needed for production. Moreover, if the price for silk from China was rising with the rising of dollars, she had to rethink of how to manage her business to survive.

There were two ways to expand markets in this business. First, by joining exhibitions in Surabaya and Jakarta. In Hj. Nurul Afrida's opinion, the exhibitions seemed to be more profit-oriented for the event organizer (EO), and pay less attention to current participants that did not have many visitors. It happened not only in Surabaya, but also in Jakarta. She even gained gross profit of nearly 3 million rupiah during a ten-day exhibition in Jakarta.

The second method to survive in this industry was by opening outlets in some locations. At present, $\mathrm{Hj}$. Nurul Afrida had three outlets: one in Pamekasan, and two in Surabaya which were located in ITC and Kapasan Market. Even though she had opened outlets, the progress of her business was not as well as she expected. Some of the causes were the imbalance between income and expenditures. The cost of renting stalls at ITC and Kapasan Market was very expensive while there were also many competitors producing batik with lower quality and lower price in the market. For example, in ITC, the rental cost was around 150 million for three years, while in Kapasan Market it was around 30 million per year.

She was then faced with a dilemma. Business started to slow for various reasons. The price of Batik was declining, while the price of fabric and threads, especially Chinese silk needed for batik production was constantly on the rise. Along with other small-scale industries and Pamekasan government, she participated in establishing a center for batik craftsmen in Klampar Proppo village in Pamekasan.

Nowadays, batik craftsmen realized that the market of Madurese batik has flourished in the market, not only in Indonesia but also in the United States and China. The Chinese has even plagiarized Madurese batik and put them up for sale in the market. "Isn't it strange?" said Hj. Hosniyah. She argued that batik craftsmen in Madura realized that many people did not care much about batik motifs. "For many people, they just know batik but do not care about the motifs and fabric quality," said $\mathrm{Hj}$. Hosniyah.

To make a qualified batik cloth with beautiful designs, it might take weeks or even months depending on the motifs and quality of the fabric. A batik cloth that used to worth around 4 million rupiahs was then sold for only 1.5 million rupiah. "The war of price and market occurs every day," she said. 
Therefore, she could only hope Madurese batik cloth, which was very heralded due to its historical and philosophical values, would always be preserved. In managing her business, $\mathrm{Hj}$. Nurul Afrida always attempted to kept the quality and designs of her batik, and she was constantly reminding her employees to be meticulous in making batik. Pamekasan batik were known to have striking colors and varied motifs. Accordingly, batik craftsmen should preserve the quality and unique characteristics of Madurese batik. "Now, when many people are able to make batik, they market their batik with no regard to its quality," she said. Of course, it might worsen the future condition of Madurese batik. "The Association of Pamekasan Batik seems to pay no heed. It could not stop the tight competition in the market," she added. On the other hand, banks did not show much support to these small-scale business according to $\mathrm{Hj}$. Nurul Afrida and $\mathrm{Hj}$. Hosniyah. Batik business did not always contribute significant effect to business people. "Now many banks only offer loans without acknowledging the condition in batik market, and so do local governments," she said.

On September 2013, she hoped to represent Madura to participate in an exhibition in London, England. She expected that the committee and East Java Government selected an experienced batik business producing high-quality batik clothes because foreigners understood the quality of Indonesian batik, especially Madurese batik. "I only hope that participants chosen for London exhibition are really the best agents of batik business, and not the people who understand nothing about batik but are relations or family of government officers," she said.

There were 3 (three) types of networks identified in this research. First, were the networks between manager/owner of small home-based industries with workers from the same neighborhood. Second, the networks occurred between the organizers and local government that provided assistance in marketing and training to support industrial progress of small home-based industries, yet not genderrelated. Third, were the networks with private sector, in this matter, related to capital access through banks, and business development through the Association of Indonesian Women Entrepreneurs. The results showed that there was no network among women in home-based industries.

\section{Model of women's empowerment in small home-based industries in Surabaya and Pamekasan}

The engagement of local communities in project design and management occurs as a popular way to gain improvement (Pritchett \& Woolcock 2004). The community-based development (CBD) approach is said to possess more convenience than the conventional top-down development programs (Grootaert \& van Bastelaer 2002). Participation in projects would not only increase the social interactions but also increase the trust between community members. Furthermore it would strengthen the mutual cooperation. If such projects can generate social capital, their impact might multiply over time as communities become increasingly empowered to control their interests.

In Bolivia, Hippert (2011) examined Bolivian popular participation as a gendered process, both in cultural context and engaging indigenous conception of participation, gender, and development. In order to achieve inclusion, collaboration, and engagement in social participation, Women attempt to sustain the prevailing conventional gender norms while they struggle to alter them. The case study reveals that development work is identity work, negotiation of different perceptions of gender identities to target groups for attention or funding purpose. Finally, gender mainstreaming has had little effect on rural women's live expect to add burden to them.

Waltz (2016) found the capacity of women in traditional farming family. They demonstrated urban functions after the phenomenon of pluriactivity came into effect in rural Southern Brazil. These functions were further evaluated using empowerment index. From the analysis, it is shown that the family is the least empowering option of the strategies that had been previously identified. Feminist provides suppport of programs arrangement which creates more equal gender dynamics. As a consequence, empowering qualities will also develop. 
In Ntcheu and Dedza in Malawi, Mudege et al. (2015) explore the potential for potato farmer groups to empower women in Malawi. It does this by examining how social and gender norms in communities, including the distribution of power, resources and responsibilities, may have an impact on the ability of farmer groups to empower female group participants. He said that women's empowerment should work closely with partners who have experience in women's empowerment because farmer group participation may not empower women if underlying social issues that result in gender inequality are not addressed (Mudege et al. 2015).

The Amazon Entrepreneurship in Brazil are examined by Mello \& Schmink (2016). The study explains that since 1985, forest policy reforms in Brazil have developed tenure rights for communities in response to both top-down pressures to halt deforestation as well as grass-roots struggles by forest peoples to protect their historical rights, and the forests for their life. (Almeida 2011, Schmink \& Gómez-Garcia 2014). Women's collective microenterprises appearance was integrated in socioenvironmental policies, focusing on community forestry and forest product markets. It functions to increase the value of non-timber forest products, reduce deforestation, and promote better living standards for forest communities (Anderson \& Clay 2002, Charnley \& Poe 2007, Vargas, 2000). There were several outstanding course to raise forest-based earnings for local people (Perez \& Byron 1999) while increasing the value of forests., such as generating the forest to be more cost-effective and fascinating for the local populations, through timber management practices and use of nontimber forest products (Nepstad \& Schwartzman 1992).

As a disadvantaged group in society, women needs better access to income through home-based activities (Hazarika \& Goswami 2016, Goswami et al. 2017). This paper analyzes women's empowerment in handloom sector in Assam, North Eastern India. Primary data was gained through 328 married women in Assam. There are five empowerment indicators observed such as decisionmaking ability, freedom of movement, ownership of assets and income, male preference and domestic violence. Results indicate existence of gaps in women's empowerment. However, there are positive influences to women's empowerment activities from education level, income from handloom activities, and government support to the group. Handloom activities also reduce the possibility of domestic violence and men's preference.

Woman entrepreneurs from small-scale enterprises generally continued their family business by using personal funds and more involved in informal sectors. In accordance with women's role in domestic tasks, most of these women entrepreneurs had chosen to manage their jobs while handling domestic tasks. Besides, working in informal sector also offered them flexible hours.

Women workers in small-scale business did not generally live in prosperity because they could not have access to business sources. Beside structural aspect, they were also restricted by natural and cultural aspects. The latter was a significant condition for the women workers. They could not be freed from domestic tasks although they were actively involved in public business, and it inadvertently has limited their movement. Therefore, most businesses managed by women entrepreneurs were within the scope of domestic sphere, for example garments, lodging, catering and restaurant (food) businesses.

Gender mainstreaming in this sector was initiated by existing organizations with the aim of empowering women in business. Accordingly, existing business was empowered with the motto "women's empowerment." Since it was very hard to turn gender mainstreaming in the field of microsmall and medium enterprises into a comprehensive policy, it was impossible to propose "affirmative action", especially for the empowerment of micro-small and medium enterprises activities at the local level (provincial and district/city).

The Association of Indonesian Women Entrepreneurs of East Java empowered women, especially in the economy, by conducting skills development training. Besides, the association also continued 
to build networks among all community groups, particularly for those who wished to become independent and self-sufficient. By being self-reliant, it was expected that women did not always depend on men and could exist more in business that helped improving the economy of the society.

Moreover, as independent women, women entrepreneurs were expected to set an example for their family. To support programs to improve women's welfare, the Association of Indonesian Women Entrepreneurs of East Java also continued to seriously conduct training and mentoring for women in various activities. This office provided various training and mentoring related to industry, not gender. Training and mentoring were held monthly, quarterly or yearly for both small and medium enterprises. In addition, the Office of Industry and Commerce of Surabaya also provided facilities to support the industry, including heavy equipment for production, business legality and business license.

The Office of Cooperatives and Small-Medium Enterprises of Surabaya provided assistance to micro, small and medium enterprises to conduct their business well through mentoring, controlling, restraining, and evaluating the products of micro, small and medium enterprises in order to meet the standard of quality. One example was technical assistance on how to be entrepreneurs and training how to enlarge capital for market expansion. Dekranasda of East Java also helped to provide facilities to exhibit featured products from small and medium industries that were selected and checked by the officials. Nevertheless, prior to the selection process, there had been training on packaging to attract consumers.

The program related to women's empowerment was conducted as agreement between BTN bank and small-medium enterprises included providing loans, conducting training on women's industries supported by the Office of Industry and Commerce with cooperatives, conducting business training in every sub-district, and elucidating Family Planning (KB) through family welfare movement, etc. The development of creative economy in Pamekasan was depicted as "Empowering human resources as main asset in the development of Pamekasan." Many craftsmen (in creative industry) in Pamekasan could actually compete with businesses from other areas, however they required supervision and counselling for product diversification and human resource training that were in line with market demands.

Several important ideas may be found from the research. In accordance with the characteristics, role, and potency of women, as well as gender relations, it is concluded as follows: First, the characteristics of formally less-educated women signified that women workers only received formal education yet not receiving any special education related to their work. Second, economic contribution to family was important yet only generating low income. In other words, the workers still kept their work even though they only paid less than the standard of the regional minimum wage. They had flexible working hours, which could be adjusted with their domestic chores. The owners of small homebased industries did not treat their workers like factory workers who had to fulfill all obligations in industrial works. Unlike formal industrial works, these workers were allowed to take a leave, have more flexible hours, and ask for soft loans. Third, there was no safety protection because they worked around their house and environment. Fourth, since these women played multiple roles as a wife, a mother and a worker, their children became 'victim' as they were left at home alone without parental supervision. Fifth, imbalance gender relations denoted that although these women played a role in the public sphere, they also took full responsibility in doing domestic chores. After arriving at home from work, they still had to do the chores on their own, while their husband did not take a share in any of those domestic tasks.

Networks formed in small home-based industries that referred to women's networks as managers/ workers in home industries were categorized into three types. First, networks established between managers/owners and workers in small home-based industries were family-like relations both for jobs and recruitment process, in which they were mainly recruited from the neighborhood. Second, 
networks between the managers/owners and the local government were in terms of marketing and training to support industrial progress of small home-based industries. Due to their limited access to capital sources, they relied on the local government to provide the necessary training. Third, networks with private sector was related to capital access through banks and business development through social organization. Results of these studies showed there was no network among women managers and workers in home-based industries. Moreover, the problems frequently faced by women managers were difficulty to get access to capital and dependence on local government due to lack of information. Furthermore, their marketing model was spontaneous and less planned. Owners of small home-based industries avoided complicated marketing plans because the most important thing for them was to be able to sell their products after production.

Model of women's empowerment in home-based industries included two types: First, the separation between empowerment program and home-based industries signified that programs initiated by the local governments only concerned with the industries themselves, and there was no program integrating between women and industries. Second, the program for women's empowerment, such as special assistance, was training for women, while special program for industrial empowerment was equipment aids. Therefore, it could be concluded that there was no model of woman empowerment by the regional government for home-based industries managed and staffed by women. The concern of government officials was to focus more on industrial development, for instance management, product quality, packaging, and marketing, without concerning the specific needs of women. In addition, there was no socialization regarding labor laws by the government through related officials and non-government organizations.

\section{Conclusion}

The results of the study showed: a) there was no special model of woman empowerment from the regional government to develop small home-based industries managed by women and employing women; b) government officials concerned more on the development of industrial management, quality, packaging, and marketing, therefore a model of empowering small home-based industries using gender perspective is required.

A model of empowering small home-based industries using gender perspective is a model of empowering small home-based industries that considers the 'specific needs of women'. It is believed that women have specific needs for both short-term and long-term. In other words, there is a requisite for practical and strategic gender needs that has to be comprehended and become the basis for the planning and development to conduct activities and programs for women.

\section{References}

Almeida AW (2011) Traditionally occupied lands in Brazil. Manaus: Universidade Federaldo Amazonas.

Anderson A \& Clay J (2002) Esverdeando a Amazonia: Comunidades e Empresas Em Busca De Praticas Para Negociações Sustentáveis. Sao Paulo: IIEB.

Charnley S \& Poe MR (2007) Community forestry in theory and practice: Where are we now? The Annual Review of Anthropology, 36:301-336.

Ihromi TO (1990) Para Ibu yang Berperan Tunggal dan yang Berperan Ganda. Jakarta: FEUI.

Surbakti S (1991) Strategi Kehidupan Rumah Tangga yang di Kepala Wanita. In: M Oey-Gardiner \& S Surbakti (eds). Jakarta: Biro Pusat Statistik.

Goswami K, Hazarika B, \& Handique K (2017) Determinants of financial risk attitude among the handloom micro-entrepreneurs in North East India. Asia Pacific Management Review, 22 (4):168-175. 
Grootaert C \& van Bastelaer T (2002) Understanding and measuring social capital: A multidisciplinary tool for practitioners. Washington, DC: World Bank.

Hazarika B \& Goswami K (2016) Do home-based micro-entrepreneurial earnings empower rural women? Evidence from the handloom sector in Assam. Asian Journal of Women's Studies, $22(3): 289-317$.

Susanti E (2009) Mekanisme Survival dan Pemberdayaan Perempuan Miskin. Yogyakarta: Aditya Media Publishing.

Susanti E (2010) Perempuan dalam Sistem Kerja "Putting Out". Surabaya: Insan Cendekia.

Hippert C (2011) Women's spaces, gender mainstreaming, and development priorities: Popular participation as gendered work in rural Bolivia. Women's studies International Forum, $34: 498-508$

Mello D \& Schmink M (2016) Amazon entrepreneurs: Women's economic empowerment and the potential formore sustainable land use practices. Women's Studies International Forum, 65:28-36.

Moser CO (1991) Gender Planning in Thirth World: Meeting Practical and Strategic Needs in Gender and International Relatioan. Open University Press: Milton Keynes.

Moser CO (1996) Confronting crisis: A summary of household responses to poverty and vulnerability in four poor urban communities. Washington DC: World Bank Group.

Mudege NN, Nyekanyeka T, Kapalasa E, Chevo T, \& Demo P (2015) Understanding collective action and women's empowerment in potato farmer groups in Ntcheu and Dedza in Malawi. Journal of Rural Studies, 42:91-101.

Nepstad DC \& Schwartzman S (1992) Non-Timber Products from Tropical Forests: Evaluation of a Conservation and Development Strategy, vol. 9. Bronx, N.Y.: New York Botanical Garden.

Perez MR \& Byron RN (1999) A methodology to analyze divergent case studies ofnon-timber forest products and their development potential. Forest Science, 45 (1):1-14.

Pritchett L \& Woolcock M (2004) Solutions when the solution is the problem: Arraying the disarray in development. World Development, 32 (2):191-212.

Schmink M \& Gómez-Garcia MAG (2014) Under the Canopy: Gender and forests in Amazonia. Publishedd in Portuguese as Embaixo do dossel Gênero e florestas na Amazônia. Bogor, Indonesia: Center for International Forestry

Shash FG \& Forden CL (2016) Gender equality in a time of change: Gender mainstreaming after Egypt's Arab Spring. Women's Studies International Forum, 56:74-82.

Vargas CM (2000) Community Development andMicro-enterprises: Fostering Sustainable Development. Sustainable Development, 8 (1):11-26.

Waltz A (2016) The Women Who Feed Us: Gender Empowerment (or lack of thereof) in Rural Southern Brazil, Journal of Rural Studies, 47:31-40. 